\title{
A Way of Life of the Zelianrong Nagas in Manipur with Special Reference to Rongmei (Kabui) Tribe
}

\author{
Kamei Beeju
}

\begin{abstract}
The Zelianrong is the combined name of Zeme, Liangmei and Rongmei(Kabui) including Puimei. These four sub tribes are more or less similar in tradition, customary laws, traditional customs, folk songs, folklore, folk dances etc. They only difference of these four tribes is that they have distinctive dialects of their own. The article portrays the perspective of Rongmei, the Naga Tribe of Manipur. It indicates all their cultural, tradition, religion, social and economic life etc. of Rongmei tribe, which has been practices since time immemorial and passed on from their fore-father to the present generation. It also attempts to set the current changes that are taking place in the Rongmei society. The data is based on available secondary sources and fieldwork. The information and opinions collected from the informants have been thoroughly cross-checked by the authors for culling out accurate facts.
\end{abstract}

Index Terms-Manipur, socio-economic, traditional religion, Zelianrong.

\section{INTRODUCTION}

The term "Zelianrong" is a composite name given to Zeme, Liangmei, Rongmei and Puimei even though "pui" is not included in the nomenclature. The Zeme and the Liangmei are officially known as Kacha Naga and the Rongmei as Kabui. But the common ancestry of the Zelianrong people is embedded in the legends and folklores of the tribe. Every Zelianrong village lived a well organised social life; based on classless society. The Zelianrong Nagas had no written form of history. They had to rely mainly on arts and culture, songs dances, legends and stories, which had been, which had been handed down orally from generation to generation [1]. The Zelianrong people live a well organised form of social life based on the classless society, there is no consideration for rich and poor, high and low etc, and all are treated equally without any distinction in the society. The elders receive special respect and honour from the people [2]. The Rongmei society joint family system was common. They believed that joint family system led to a harmonious family relationship. As custom the youngest son inherited his father's property. The father as the head of the family possessed certain rights and had to perform some duties to run the family affairs. The eldest son in the family shouldered most of the responsibility after the death of his father.

The Rongmei tribe have well-coordinated social system since time immemorial. They are, in fact known to love

Manuscript received July 1, 2013; revised September 11, 2013.

Kamei Beeju is with the Indira Gandhi National Tribal University-RCM India (e-mail: junakams@gmail.com). permanent dwellings .The Villages are the units' basic unit of the society and social units were kin groups, lineages, clan etc. They practise their religion; observe their festivals and marriages ceremonies. In the social units, clan also strengthens the bonds of relations and it recognises relationship only through one of the parent's side and therefore, it is unilateral kinship group. The Rongmei is a patriarchal society with many exogamous clans and sub clans. The clans have its totems. The most important which keeps different clans of the Rongmei closely connected is the system of marriage which does not allow that husband and wife belongs to the same clan.

\section{RELIGION}

The Rongmei religion has been there since time immemorial. It is a historically and traditionally evolved religion. The people were the follower of a well set traditional religion supreme God known a "Ragwang" in community. They prayed before the deities and household god. They were conversant with the concept of soul, salvation of soul, rebirth, sin morality and life after death. In general terms as interpreted by the western writers, the religion of the tribe was described as animism [3]. They believed in the supreme God whose nature was benevolent. According to their beliefs, he is above the sky. He was worshipped separately through rites, ceremonies or sacrifices and offering during festivals for good health, prosperity, good harvest, etc. All the ceremonies were performed in his name. They also worshipped the spirit of their ancestors as protectors of their household and family as some brought good fortunes while some brought misfortune.

\section{CUSTOMS AND TRADITION}

The socio-economic, political and the cultural life of the Zelianrong people are governed by the traditional unwritten customary law. According to the customary laws, when a baby is born, the first ritual is performed, offering a chicken and sacrifice to the god of the village and cast away the evil spirit from the baby. According to the traditional customary laws of the Zelianrong tribe, if a dog happened to climbed up at top of the house roof, it is considered as bad omen for the owner of the dog as well as for the whole villages. And that particular dog which has been climbed up to the roof of the house should not enter the house and should be killed [4].The society is well knit social Institution in connection with the life of an individual. He /she are always associated with an institution of person of his or own age group and its membership and social rank is determined in accordance 
with one's age grade. The social institutions in the life of an individual are as follows;

Marriage Institution: According to the concept of Rongmei, marriage is contract between two spouses through family which social religious sanction. Marriage is the unique system of permanent union of male and female for the purpose of having children to continue a line of future generation as family unit and transmission of culture through it. According to customary laws, marriage is considered as one of the most important aspects in life, because it involves rites and rituals which are performed in the name of god. The act of marriage is performed by the priest or an elder of the village. The term marriage is known as "Nousuanmei" among Rongmei. Monogamy is the general rule of marriage among the Rongmei. Polygamy though accepted in the Rongmei society is of rare occurrence [5]. Child marriage is totally absent. According to customary laws, marriage considered as one of the most important aspects in life, because it involves rites and rituals which performed in the name of god. In the society the man who does not have a wife is not entitled to hold an important position in the village council. In the case of divorce, he/she is to let the matter know to the village council on the terms based on customs. Here, girls cannot go to her maternal place alone, she to be assisted by a group of "Mathenmei"(Women Society).Women who will intimate the girls' family the causes of the divorce are handed over the girl to her family.

Death: Death is an inseparable part of a human being. There are two types of death i.e. natural death and unnatural death. In case of unnatural death the corpse are not allow to take inside their house or they are not buried in the village. However with the formation of Rongmei religious council it had abolished all taboos connected with unnatural death. Unnatural death are death due to snake bite, taking one's own life, death due to accident and drowning and death due to animals bite[6].

\section{ECONOMIC LIFE OF RONGMEI/KABUI}

Agriculture is the main stay of the economy of the Rongmeis. Apart from its economic importance, it also brought a new development in their society that it laid a foundation for establishment of a settled life among Rongmeis. Right from the earliest period of time the agricultural practice was shifting or the jhum cultivation. Today, their way of farming witness remarkable changes and now, they have begun to adopt wet or terrace cultivation. Shifting cultivation is an age old method of agriculture practised in all areas inhabited by tribes[7].Shifting cultivation is commonly practised in tropical and sub tropical countries mainly in south East -Asia, Africa and Latin America. In India it is mostly confined to North East India and is the main occupation of almost all tribes of the region. The traditional way of land cultivation among the Zelianrong starts with the reading of omen locally known as "Inchildaan-Saanmei [8].With the help of omen reading by the elders of the village particular block of jhum land for annual cultivation varies from five to ten years. The crops grown in the jhum fields are paddy, maize, millet, chilli, ginger, potatoes and other vegetables. Rice is grown in large quantity, as it forms the staple food of the people. Though agriculture is the main source of livelihood, livestock farming plays a prominent role in their economy. Each and every house domesticates animals. Piggery and poultry are of equal importance. They rear animals for necessary requirements to be used during genna, public functions, festivals and feast of married. Apart from the agriculture and farming, cottage industries like weaving and dying is done by the women folks. Expert in weaving is still the merit of a bride and therefore, it is indispensable work among the Rongmei womenfolk. The Rongmei have techniques of dying thread into various colours .In order to dye the thread the tribal people used various kinds of creepers, leaves, barks and other species.

\section{VILlaGE ADMINISTRATION}

The traditional political system of the Rongmies is somewhat similar to the present form of government i.e Democracy, However gerontocracy is their form of government, according to which the whole administration of the village is managed or regulated by the village elders. The village council of elders carried on the administration of the Zelianrong village. Each village had own village council called as "Feiki" in Zeme, "Paiki" in Liangmei and "Peikai" in Rongmei, composed if all the adult male members of the village of which the chief was the head. All the villagers rich or poor were answerable to the village council. The people of Zelianrong help the village council in high esteem [9].

\section{A. Basis of Membership}

For the membership of the village the size of the village was to be taken not considerations. There was representation from all the clans. Women were debarred from the membership of the village council. The composition of member powers and functions of the council varied from village to village, but the basis structure remained more or less the same and uniform

\section{B. Power and Structure}

The village council possessed administrative powers of the village. The village Council or Pei was a legislative organ of the village. General administration and formulation of policies were framed by this council. The council preserved cultural, customary and conventional laws. It had power to amend customary laws and incorporate new laws [10].The powers and functions of the village council could be broadly divided into the following categories: Executives, Legislative and Judicial.

\section{1) Executives function}

The village council was the most powerful executive body in the village administration. The decision of the council on all important matters was binding and final. It maintained inter village relations. The council members were the sole authority to enforce customary law and amend the unwritten customary laws which they followed. The council members commanded villagers in their jurisdiction, executed orders, took action against any village for violation of the order. The council was responsible for maintaining peace, harmony and unity of the village. 
Administration of the village was carried out by the village council. In case a person failed to abide by the decision of the council, the council had to take necessary actions against the person concerned as there were innumerable taboos in the society. Customary laws had such far reaching effects aiming the Zelianrong people that they dare not trespass the sanctions of the customary laws. The village council administers justice; allocated land for cultivation decided the time for annual festivals, sacrifices and generally, directed all the village social, religious and economics according to their traditional laws and customs. The village council also dealt with the financial matters. Paddy in lieu of money or money in lieu of services was to be collected from the villagers. Also, any fine imposed on an individual was to be reserved for the council's funds. In the religion side, the village council was not taken as the real authority of religious rites and rituals but it had certain rights in this field too. The religious head of the village was the village priest and elders of the village constituted the council. The priest always consulted the village council on matters of religious festival and performed all the traditional ritual ceremonies. The council enforced the villagers to maintain strict observation of taboo [11].

\section{2) Legislative function}

The council being the general body framed laws and customary rules and regulations from time to time. Such rules and regulation were made when all the villagers attended the council in full strength. Sometimes, it was observed that the council could adopt even new laws concerning marriage, theft, property and land to meet the demand of time and situation. In the legal system of Zelianrong people, there was no capital punishment as such. The hardest punishment was imposition of fines and banishment of individual from the village. Though there was no written law, the Zelianrong people strictly adhered to time tested customary laws handed down by their predecessors. These customary laws worked effectively in the minds of the people for these were inherent in their lives and society.

\section{3) Judicial function}

The village council of elders also worked as the chief court of the village. The chief who was the supreme judge in deciding all civil and criminal case of the village headed the council. The village council was the single court of justice and heard cases disputes and passed verdicts. If the nature of the case was small only few members could settle it. But if the case was small only few member should settle it, But if the case was serious such as adultery murder or death involving some perpetrators, the entire household representatives were to be called to attend the meeting [12]. The Zelianrong society like all other Nagas tribes was based on the unwritten customary laws. Imposition of times, punishment and justification of any case was done on the basis of these Zelinarong customary laws. All kinds of disputes and difference between families of the same clan were as far as possible decided by the clan elders. But if they could not solve the problems, the cases were brought to the village court [13]. Both criminal and civil cases were tired by the council, which passed final judgements. These decisions were given by well experienced elderly representatives of all clans. If the cases were vague and could not be solved peacefully, then the village council resorted to taking of oath and ordeal in a boundary disputes, theft etc. witness were to be produced. Likewise the polity of government to which the administration the Zelianrong people is also democratic in nature. However, gerontocracy is their form of government to which the administration of the village is under the control of the village elders [14].Among the tribes of Zelianrong is known for the rich socio cultural heritage. Rongmei festivals have more elaborated reflecting the attitude towards social organizations, agricultural development, maintenance of ponds and paths, seed sowing and towards religion and war. The following festivals of the Rongmeis are indicative of the growing philosophy of Rongmei people [15].

- Nanu Ngai(ear boring festivals of the children)

- Napkaodai(Ginki) Ngai( seed sowing festival)

- Gudui(Maleng) Ngai(completion of seed sowing cultivation festival)

- Tun Ngai(Festival of rains to improve ponds, paths and village street)

- Ten Ngai(Festival of Bun)

- Puakphat Ngai(Festival of new crops)

- Chakak Ngai(Soul departing festival)

- Donjao Ngai /Banchat Ngai (Declaration of the largest producer of paddy)

- Gaan Ngai (chaga)( Winter festival)

- Rih Ngai(Festival of War)

Zelianrong people celebrate all kinds of festivals when the moon ascends but never observe them when moon descends. Among of all the festivals, Gaan Ngai is regarded as the biggest festival. In this festival, reflection of the Zelianrong belief, pattern of society and cultural practices are found. It is regarded as an identity festival [16]. Gaan Ngai literally mean the festival of winter season. (Gaan means dry or winter season, Ngai means festival). The Gaan Ngai is also a post harvest festival. When the granaries are full, the landscape is dry, the whole village is free from all agricultural works, and people turn to celebration, festivity and worship of the God and honouring of the dead. The Gaan Ngai is also a festival during which those who died in the previous year are given ritual farewell, their graves are beautiful, dances are performed in their honor, and feast is given to the community in the honor of the dead. Thus, this festival is the festival of both dead and living [17]. The Gaan Ngai is celebrated in the month of December-January. It is religious cultural and customary festival lasting for 5-7 days depending on local variation. Each day of these festivals has its own name, speciality and ach act in these days has its significance.

\section{CONCLUSION}

The Zeliangrong People are one of the major indigenous mongoloid communities living in the tri-junction of Assam, Manipur and Nagaland. And Manipur, one of the most inhabited by different communities. It is lands of unity and diversity. There are 29 tribes in the province. The spread of education among the Zelianrong had also brought changes in the society. The greatest changes took with the coming of Christianity. The traditional life of Zelianrong people had 
undergone a great transformation as they discarded their old religious beliefs, rites and sacrifices ceremonies etc. But at the same time there are people who still follow the ancestors religion (i,e Tingkao Ragwang) and preserve the identity of the Rongmei traditions and culture. Rongmei Nagas have our own social traditional and cultural identities preserved from generation to generation. The Rongmei have very much rich heritage of custom and culture among the Nagas which are the sources of joy and happiness of life.

\section{REFERENCES}

[1] S. Irene, "Socio and cultural life of the tribal before the advent of christianity," Seminar paper organised by Manipur University Tribal Students Union, Manipur University, Imphal, 2001.

[2] R. Gangmei, "Political, socialization of Tamenglong district, Manipur," M. Phil Dessertation, Dept. Political Science, IGNTURCM, 2012.

[3] G. K. Gosh, Tribals and their Culture Manipur and Nagaland, vol. 3 , Delhi Ashish Publishing House, pp. 63, 1992.

[4] K. Sanjit, "Zelianrong in the 21st century," Souvenir Zelianrong Students Union, Manipur, Diamond Jubilee cum 20th General Conference of the Zelianrong Students Union (AMN), pp. 64, 2010.

[5] C. Panmei, "Traditional political system of Zelianrong tribe of Manipur," M. Phil Dissertation, Dept. Political Science, Indira Gandhi National Tribal University, Manipur, India, 2012.

[6] C. Panmei, "Traditional political system of zelianrong tribe of Manipur," M. Phil Dissertation, Dept. Political Science, Indira Gandhi National Tribal University, Manipur, India, pp. 41, 2012.

[7] L. Jeyaseelam, Impact of the Missionary Movement in Manipur, Scholar Publishing House, pp. 45, 1996.

[8] Thuanliang, "Shifting cultivation, A way of life of the Zelianrong in souvenir," Zelianrong Naga Festival cum Seminar, Imphal, pp. 95, 1995.

[9] Interview with Keineguang Gangmei, village elder on 7th December Tamemglong, 2010.

[10] R. H. Gonmei, Mairam (torch), A Brief History of Dailong Baptish Church, 1928-1980, Imphal, pp. 22, 1980.

[11] T. H. B. C. Singh, "The socio-economic life of the Zeme Naga in the 12th Century," Ph.D thesis, Manipur University, 1996, pp. 92.

[12] T. H. B. C. Singh, "The socio-economic life of the Zeme Naga in the 12th Century," Ph.D thesis, Manipur University, 1996, pp. 95.

[13] V. V. Rao, A Century of Tribal Politics in North India (1876-1974), S. Chand and Company, Delhi, pp. 124, 1976.
[14] M. Thaimei, The Rongmei's in Manipur Past and Present, vol.3, pp. 407, Delhi, 1995.

[15] J. Kamei, Gaan Ngai: A Festival of the Zelianrong Nagas of North East India, North Eastern Zone Cultual Centre, Ministry of Culture, Government of India, Dimapur, pp. 55-59, 2012.

[16] Statement of Mr. Pouhomrung kamei (Sangaiprou village elder), personal interview, 2013.

[17] G. Kamei, Gaan-Ngai: A Festival of Zelianrong People of North East India, Gaan Ngai Celebration Committee, Manipur, pp. 1-3, 2003.

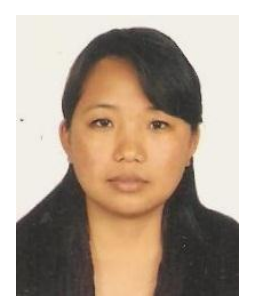

Kamei Beeju was born on First March 1982, in the erstwhile Asiatic sovereign Kingdom of Manipur, which is located in India's North Eastern Region.

Kamei completed her school education and Graduated from Imphal, Manipur. She received her Master's Degree in Social Work with specialization in Community Development from MSS Institute of Social Work, Nagpur University in 2007.She cleared the National Eligibility Test for Lectureship- a National Examination conducted by University Grant Commission, Government of India. Later continue for Ph.d Programme in School of Social Work, Assam University, Silchar -India(on Rajiv Gandhi National Fellowship for Schedule Tribe) In Nov.2011, she was awarded the Doctor of Philosophy in Social Work for her thesis entitled, "A study on HIV/AIDS Affected Widows in Imphal, Manipur".

Right after her Master's Degree, She works as social worker in the Centre for Mental Hygiene, Imphal for a short period of seven months. In 2012 August she was appointed as Assistant Professor in Department of Social Work, Indira Gandhi National Tribal University-Regional Campus, Manipur.

Kamei authored at different platform. Some of her articles publication includes:

1) Kabui Mother's Association and Peace Building in Manipur, Conflict transformation Peace and ethnic Divide, In India's northeast: The context of Recent Trends, Kamakhya Publication 2013, India.

2) The level of awareness about HIV/AIDS between student and nonstudent youth in Imphal: The role of social worker in the helping process, Social Work Journal, Assam University SilcharVol.3,No.1, 2012.ISSN 0976-5484.

Her area of research interests includes Gender Studies, Tribal Studies; Health related Studies and many more.

Dr. Kamei, presently a life member of Indian Sociological Society. She was awarded as the most punctual Teaching staff (2012-2013) by the Indira Gandhi National Tribal University Student Union-Regional Campus Manipur. 